Bayero Journal of Pure and Applied Sciences, 10(1): 133 - 136

ISSN $2006-6996$

\title{
MUTATION BREEDING AS PANACEA FOR FOOD SHORTAGE AND MALNUTRITION IN NIGERIA'S SAHEL (A REVIEW)
}

\author{
*Nura, S., ${ }^{1}$ Mairami, F.M., ${ }^{2}$ and Negbenebor, H.E. ${ }^{2}$ \\ 1. Department of Biology, Ahmadu Bello University Zaria, Nigeria. \\ 2. Department of Computing and Applied Science, Baze University, Abuja, Nigeria. \\ ${ }^{*}$ Corresponding Author: salisunura40@yahoo.com, GSM: +2348031513910
}

\section{ABSTRACT}

The Nigeria's Sahel characterized as semi-arid zone is faced with several environmental degradations due to natural and artificial factors. The natural factors are incessant droughts, desertification and short rainy season that limit crop production and decrease yield. The artificial factors include deforestation to feed more mouths and religious upheavals. These problems lead to low crop yields and inability of the subsistence agriculture to meet their social demands with increased spate of malnutrition, hunger and starvation. Victims abandoned their farmlands to seek refuge in the urban and semi-urban centers of the country thereby leaving the land barren. Efforts are therefore needed to boost food production in the area. Mutation breeding is one of the best methods employed nowadays to improve crops quality and quantity. It provides the ability of producing crops that are stress tolerance, longer life span, early maturing, high nutritional composition and yields with low agronomic in-puts This study therefore aimed at reviewing the role played by mutation breeding in improving crops quality and quantity so as to call the attention of the scientific community and the authorities concerned upon the application of mutants varieties in the area to boost crops production, call the attention of the refugees back to farm and enhance national development. Priority crops such as cereals and legumes as well as vegetables needed in the diets ought to be improved by artificial mutagenesis. The method unlike others is more reliable, more ethical and safer. It provides crops that are better in both nutritional quality and quantity and hence safer to consume.

Key Words: Food shortage, Mutation, Sahel, Semi-arid.

\section{INTRODUCTION}

The Nigeria's Sahel savanna zones situated north of latitude $12^{052} \mathrm{~N}$ was characterized as semiarid. The area receives between $200 \mathrm{~mm}$ to $800 \mathrm{~mm}$ of rainfall annually (IIED, 1989). The area is threatened by recurrent ecological disasters such as drought, desertification and social unrests mostly associated with anthropogenic factors (UNCCD, 2004). These ecological disasters coupled with the social upheavals such as the Maitatsine revolts in the early $80 \mathrm{~s}$ and the recent Boko Haram crises in the area led to emigration of the people in the area, abandoning the farmlands to the tender mercies of direct rain drops and winds with subsequent effect of declined in soil fertility with increased rise of malnutrition and starvation. Concerted efforts are therefore needed by the governments and the scientific community to call the attention of the emigrants back to their farmlands to restore the land by introducing mutant seeds that are high yielding, early maturing, and stress tolerant that need low agronomic in-puts. This will boost food production and provide sustainable nutrition.
Mutation (a change in genetic material of an organism) induced both in seeds and vegetatively propagated crops is of scientific and commercial interest to improve the quality, growth and yield related attributes of plants. It facilitates the development of improved varieties and has been successfully utilized to improve yield components of various crops (Naik and Murthy, 2009). It provides raw materials for the genetic improvement of economic crops (Adamu et al., 2004). It facilitates the isolation, identification and cloning of genes which would ultimately help in designing crops with improved yield, increased stressed tolerance, and longer life span and reduced agronomic in-puts (Ahloowalia and Maluszynski, 2001). This study therefore aimed at reviewing the potential roles played by mutations in creating variability that could be exploited in the improvement of economic crops that could tolerate the harsh environmental conditions of the Nigeria's Sahel to meet the needs for poverty stricken populations. 
Induced Mutation Technology for Crops Improvement

The idea of producing artificial mutations and utilizing them for breeding cultivars plants was initiated as early as 1901 by the induction of mutations for factors which govern the heredity of quantitative characters as a promising tool for releasing new genotypes (Gomaa et al., 1995). It is an established fact that mutagen, besides causing changes in major genes, also induce mutations at loci governing the quantitative characters. Mutagenic agents offered great possibilities for increasing genetic variability of quantitative traits such as yield and growth parameters.

Mutation induction has been successfully used to induce genetic variability in many crops, allowing to isolate mutants with desirable characters of economic importance such as increased seed yield, earliness (Wongyai et al., 2001), modified plant architecture, closed capsules, disease resistance (Çagirgan, 2001), seed retention, larger seed size, desirable seed color and high oil content (Hoballah, 2001). Crop improvement therefore depends on the genetic variability and the extent to which the traits are heritable. There have been innumerable studies on variability, correlation and path analysis for effective selections. The genetic investigation on these parameters is a prerequisite for planning any breeding programme (Yaligar, 2005). Genetic variability for traits of agronomic importance is often limited among cultivated germplasms. Many new cultivars of plants have been directly or indirectly released in the world through induced mutations. The number of mutant varieties officially released and recorded in the FAO/IAEA Mutant Variety Database by the beginning of the $21^{\text {st }}$ century reached 2252 varieties for such crop as cereals, oilseeds, pulses, vegetables, fruits, fibers and ornamental plants (Kharkwal et al., 2004).

Implications of Mutation to Improved Survival and Yield

Although the issue of altering the genetic make-up of food crops to meet the needs for the growing human population in the $20^{\text {th }}$ century is still controversial, however, mutations were found to be beneficial in improving the survival rate of different plant cultivars and their yield parameters. The mutation induction technique has provided the development of new genotypes with desirable agronomic traits. Better grain yields were found in the mutants of wheat inbred lines originated from hybridizations with gamma irradiations (Camargo et al., 2005). Mutation induction was found to have heterotic effects on many plant species including such important crops as: barley, faba bean, maize, pea, pearl millet, rice, sunflower, sweet clover, triticale and wheat (Maluszynski et al., 2001).

Mutant heterosis was reported for crosses of spontaneous mutants, mutants obtained after treatment with various mutagens and recently also for somaclonal variants. The heterotic effects are usually related to increase in some yield components (Maluszynski et al., 2001). Grain weight per plant was found to be improved by artificial induction of mutation in barley (Polok et al., 1997), while Stelling (1997) reported the improvement of grain yield, podded lateral branches per plant, pods set and biomass in faba bean mutants. Increase in seed number per plant (Lonnig, 1982), and seed weights (Rybtsov et al., 1997) were found in pea mutants. Rai et al. (1986) reported an increase in seed yield in crosses between mutants and pure lines of pearl millet. Increase in seed yield (Adamu et al., 2004), number of capsules per plant and 1000 seeds weight (Hoballah, 1999) were found in sesame mutants. Grain weight per plant (Konzak, 1989) and yield per plot (Gale et al., 1988) were found to be increased due to artificial induction of mutation in wheat. Semi dwarf mutants with increased vigor in terms of yield, grain weight and number of tillers were reported in rice (Anandakumar and Sree-Rangasamy, 1995). Mutation in sunflower was found to increase seed yield and seeds weights (Zinovatnaya et al., 1995). Soya beans mutants have been produced with reduced palmic acid level from $11 \%$ to $4 \%$ (Fehr et al., 1991). There were increase in the number of pods, length of pods, seed size, grain yield and number of seed per pod observed in the 15 families of $M_{3}$ mutants of Latharus sativa L. (Waghmare and Mehra, 2000). Increased pod length and high yield was also observed in $M_{2}$ mutants of cowpea (Pathak, 1991).

Mutation Breeding as Panacea for Food Shortage and Malnutrition in the Nigeria's Sahel

Mutation breeding can therefore provide useful mutants that are high yielding and early maturing that can withstand both biotic and abiotic stress. This can boost agricultural production, provides income to farmers, call the attention of the emigrants back to their original farmlands, stimulates foreign investments and restore soil fertility. The area that is left barren will be restored in to greener pasture to support agricultural activities, thereby reducing malnutrition and starvation in the area. The attention of the authorities is therefore needed upon reclamation of such poverty stricken area.

\section{Conclusion}

It was concluded that induced mutation is a useful tool to be used in the Nigeria's sahel to create new improved genotypes that are early maturing, high yielding and stress tolerant that need low agronomic inputs for their cultivation. 
These mutants can be used in the area to boost agricultural development by increasing food basket and generate income to both the farmers and the nation.

\section{REFERENCES}

Adamu, A. K., Chung, S.S., and Abubakar, S. (2004): The effect of ionizing radiation (Gamma rays) on tomato (s.n.), Nig. Journal of Expt. Biol, 5(2):185-193

Ahloowalia, B.S., and Maluszynski, M. (2001): Induced mutation: A new paradigm in plant breeding, Euphytica, 118:167-173.

Anandakumar, C. R. and Sree-Rangasamy, S. R. (1995) Heterosis and selection indices in rice. Egypt J. Genet. Cytol., 14:123-132.

Çagırgan, M. (2001): Mutation techniques in sesame (Sesamum indicum L.) for intensive management: Confirmed mutants. In: Sesamelmprovement by Induced Mutations. IAEA-TECDOC-1195, IAEA, Vienna, pp. 31-40.

Camargo, C. E. O., Ferreira Filho, A.W.P., Neto, A.T., Jjunior, A.P.,De Castro, J.L., Felicio, J.C.M., and Solomon, M.V. (2005): Evaluation of wheat inbred lines originated from hybridizations with and without gamma irradiation. Bragantia Campinas, 64(1):61-74.

Fehr, W.R., Welke, G.A., and Hammond, E.G. (1991): Inheritance of Reduced palmic acid content in seed oil of soya beans; Crop Sci., 3:88-89.

Gale, M. D., A. M. Salter, F. C. Curtis and W. J. Angus (1988): The Exploitation of the Tomn Thumb dwarfing gene, Rht3 in $F_{1}$. hybrids wheat. In: Semi-Dwarf Cereal Mutants and Their Use in Cross-Breeding III. IAEA Vienna, pp 57-68

Gomaa, M.E., El-Hissewy, A.A., Khattab, A.B., and Abd-Allah, A.A. (1995): Improvement of yield and some related characters of rice (Oryza sativa L.) by irradiation. Menofiya Journal of Agricultural Research, 20(2): 395-408.

Hoballah, A. A. (1999): Selection and Agronomic evaluation of induced mutant lines of sesame. In: Induced Mutations for Sesame Improvement. IAEA-TECDOC, IAEA, Vienna, pp 71-84.

Hoballah, A.A. (2001): Selection and agronomic evaluation of induced mutant lines of sesame. In: Sesame Improvement by Induced Mutations. IAEA-TECDOC-1195, IAEA, Vienna, pp. 137-150.
The use of mutant varieties can stimulate interests in agriculture, poster rural development, assists in land reclamation and thereby reducing the pressure placed by the country's economy on crude oil exportation.

International Institute for Environment and Development IIED. (1989): Paper No 14. Information kit, The IUCN Sahel programme, December, 1989.

Kharkwal, M.C., Pandey, R.N., and Pawar, S.E. (2004): Mutation breeding for crop improvement. In: Plant breeding. Mendelian to molecular approaches. H.K. Jain, M.C. Kharkwal (eds), Narosa publishing house, New Delhi, India, pp.601-645.

Konzak, C. F. (1989): Exploitation and analysis of heterosis in wheat with induced mutations. In: M. Maluszynski eds., Current Operatios for Cereal Improvement. Kluwer Academic publishers, Dordrecht. pp. 97-113.

Lonnig, W. E. (1982): Dominance, overdominance and epistasis in Pisum sativum L. Theor Appl. Genet., 63:255-264.

Maluszynski, M., Szarejko, I., Barriga, P., and Balcerzyk, A. (2001): Heterosis in crop mutant crosses and production of high yielding lines, using doubled haploid systems. Euphytica. 120:387-398.

Naik, P.M., and Murthy, H.N. (2009): The effects of gamma and ethyl methane sulphonate treatments on agronomical traits of niger ( $G$. abyssinica Cass.). African Journal of Biotechnology, 8(18): 4459-4464.

Pathak, R.S. (1991): Genetic evaluation of two Aphids resistant cowpea Mutants in Kenya. In: Plant Mutation Breeding for Crop Improvement, (2) I.A.E.A. Vienna pp 241247.

Polok, K., Szarejko, I., and Maluszynski, M. (1997): Barley mutant heterosis and fixation of $f_{1}$ performance in doubled haploid lines. Plant Breed, 116:133-140.

Rai, K.N., D.J., Andrews and A.S. Rao (1987) Hybrid potential of 18A: A dwarf male sterile line of pearl millet. Indian J. of Genet. Plant Breed. 46:295-303.

Rybtsov, S.A., T.A. Ezhova and S.A. Gostimskii (1997): Use of in vitro tissue culture to study heterosis in the Pea. Russian J. Genet., 33(11):1299-1303.

Stelling, D. (1997): Heterosis and hybrid performance in topless faba beans (Vicia faba L.). Euphytica, 97:78-29. 
United Nations Convention to Combat Desertification (UNCCD) (2004): A carrying Pillar in the Global Combat against Land Degradation and Food Security. Background Paper for San Rossore Meeting "Climate Change, a New Global Vision” Pisa Italy, 15-16, July, 2004.

Waghmare, K.N. and R.B. Mehra (2000): Induced mutation in grass pea (Lathyrus sativus L). Lathyrism Newsl, pp 786-796.

Wongyai, W., Saengkaewsook, W., and Veerawudh, J. (2001): Sesame mutation induction: improvement of nonshattering capsule by using gamma rays and EMS. In: Sesame Improvement by Induced Mutations. IAEA-TECDOC-1195, IAEA, Vienna, pp. 71-78.
Yaligar, S.B. (2005): Genetic evaluation of segregating populations involving spiny and non -spiny genotypes of safflower (Carthamus tinctorius L.) for productivity and oil content. An M.Sc. Thesis (Unpublished). Department Of Genetics And Plant Breeding, College Of Agriculture, Dharwad, University Of Agricultural Sciences, Dharwad

Zinovatnaya, G. N., I. I. Ulitcheva and E. P. Guskov (1995): Combining ability of sunflower plastom mutant lines and expression of heterosis for quantitative traits in intermutant hybrids. Russian J. Genet., 31(12):1423-1429. 